\title{
Tailored dosimetry in the radioiodine treatment of differentiated thyroid cancer
}

Citation for published version (APA):

Wierts, R. (2018). Tailored dosimetry in the radioiodine treatment of differentiated thyroid cancer. [Doctoral Thesis, Maastricht University]. Datawyse / Universitaire Pers Maastricht. https://doi.org/10.26481/dis.20180530rw

Document status and date:

Published: 01/01/2018

DOI:

10.26481/dis.20180530rw

Document Version:

Publisher's PDF, also known as Version of record

\section{Please check the document version of this publication:}

- A submitted manuscript is the version of the article upon submission and before peer-review. There can be important differences between the submitted version and the official published version of record.

People interested in the research are advised to contact the author for the final version of the publication, or visit the DOI to the publisher's website.

- The final author version and the galley proof are versions of the publication after peer review.

- The final published version features the final layout of the paper including the volume, issue and page numbers.

Link to publication

\footnotetext{
General rights rights.

- You may freely distribute the URL identifying the publication in the public portal. please follow below link for the End User Agreement:

www.umlib.nl/taverne-license

Take down policy

If you believe that this document breaches copyright please contact us at:

repository@maastrichtuniversity.nl

providing details and we will investigate your claim.
}

Copyright and moral rights for the publications made accessible in the public portal are retained by the authors and/or other copyright owners and it is a condition of accessing publications that users recognise and abide by the legal requirements associated with these

- Users may download and print one copy of any publication from the public portal for the purpose of private study or research.

- You may not further distribute the material or use it for any profit-making activity or commercial gain

If the publication is distributed under the terms of Article $25 \mathrm{fa}$ of the Dutch Copyright Act, indicated by the "Taverne" license above, 


\section{Summary}



The aim of this thesis was to improve radiation dose assessment in radioiodine treatment in differentiated thyroid cancer (DTC), both for the application of personalized patient treatment using quantitative ${ }^{124}$ I PET imaging and radiation protection of personnel and the general population. With respect to patient management, the application of lesion dosimetry, based on pre-therapeutic ${ }^{124}$ I PET, may provide valuable prognostic information and allow for a personalized radioiodine treatment approach. A personalized radioiodine treatment approach facilitates dose escalation and may improve patient outcome, which is in particular important for high-risk DTC patients. In addition, for patients presenting with lesions showing high radioiodine uptake, a personalized treatment approach may yield lower amounts of radioiodine used in therapy and result in less adverse effects.

From the perspective of radiation protection, accurate dosimetry allows for improved shielding designs in radionuclide therapy facilities that are safe, cost effective and in line with the applicable legislation.

In Chapter 1 a general introduction on the application of radioiodine therapy in DTC is provided. In addition, the concept of performing personalized pre-therapeutic lesion absorbed dose assessment for radioiodine therapy in DTC, based on hybrid PET/CT and $\mathrm{PET} / \mathrm{MRI}$ imaging, is described. Finally, the use of Monte Carlo-based dosimetry, aimed at radiation protection of visitors and personnel in radioiodine treatment, is discussed.

Chapter 2 provides a review of the literature with respect to personalized dosimetry approaches and relevant developments in molecular nuclear therapy. It is shown that advanced personalized dosimetry in radionuclide therapy is feasible and that developments in nuclear medicine imaging instrumentation and dosimetric software are evolving at a high pace. However, personalized procedures developed so far differ in approach and sophistication, and standard operating procedures necessary for a widespread implementation are only scarcely available.

In Chapter 3, the dose-response relationship of radioiodine therapy using a fixedactivity approach is retrospectively investigated for DTC by means of lesion absorbed dose assessment based on ${ }^{124}$ I PET/CT examinations that were performed prior to the therapy. Using a novel segmentation technique, allowing accurate lesion volume estimation down to the ${ }^{124}$ I PET spatial resolution volume, we found that lesions showing complete lesion response to the radioiodine therapy received a statistically significant higher lesion absorbed dose compared to lesions showing no or incomplete lesion response. In addition, receiver-operating-characteristic curve analysis demonstrated that pre-therapeutic ${ }^{124}$ I PET/CT lesion dosimetry can be used as a prognostic tool to predict lesion response to radioiodine therapy.

Accurate ${ }^{124}$ I PET quantification, and thus lesion dose assessment, is affected by the detected prompt gamma coincidence (PGC) events of ${ }^{124}$ I. In recent years, different techniques for PGC correction have been investigated and have become commercially available. In Chapter 4 we investigated the impact of a PGC correction technique on ${ }^{124}$ I $\mathrm{PET} / \mathrm{CT}$ quantification for both phantom and patient data. In addition, the effect of PGC 
correction on calculated lesion absorbed dose was determined. In phantom measurements, PGC correction substantially improved background uniformity. In addition, PGC correction resulted in significant higher sphere recovery coefficient values, measured ${ }^{124}$ I lesion uptake and calculated absorbed lesion dose and should be applied whenever available.

Due to the superior soft-tissue contrast of MRI compared to CT for head-neck imaging, ${ }^{124}$ I PET/MRI may become increasingly important in DTC patients. However, compared to $\mathrm{PET} / \mathrm{CT}$, in which a relatively straightforward CT-based PET attenuation correction is applied, quantitative PET/MRI is more challenging. In Chapter 5 the quantitative performance of ${ }^{124} \mathrm{I}$ PET/MRI, aimed at performing lesion dosimetry in DTC patients, was investigated. Using phantom measurements, it was shown that the ${ }^{124}$ I radioactivity concentration was underestimated by $12 \%$. The influence of radiofrequency coil attenuation on ${ }^{124}$ I quantification was less than $5 \%$ and considered negligible. For bonesimulating lesions, standard MR-based attenuation correction, in which bone tissue is ignored, resulted in an additional underestimation of the ${ }^{124}$ I activity concentration. This underestimation increased with increasing lesion density and diameter. In a clinical setting, an excellent agreement between PET/MRI and PET/CT segmented lesion volume and mean ${ }^{124} \mathrm{I}$ radioactivity concentration was observed for DTC patients. Therefore, we concluded that accurate lesion dose assessment in DTC patients is feasible based on ${ }^{124}$ I PET/MR imaging.

Besides lesion dose assessment in patients, radiation dose calculations are also important in the shielding design of nuclear medicine therapy facilities. In practice, the shielding in walls is often limited to a height lower than the actual ceiling height. Consequently, radiation traveling over the shielding material and scattered by the ceiling may result in an important contribution to the radiation dose outside the radionuclide treatment facility. Using Monte Carlo simulations, in Chapter 6 this contribution of ceiling scattered radiation to the total radiation dose was investigated. As expected, we found that the shielding required for the primary radiation, measured in half-value layers, is an important factor in the relative contribution of ceiling scatter. In fact, when more than about four half-value layers of shielding are used, ceiling scatter becomes the dominant factor and should be taken into account in the shielding design. The results of this study will facilitate improvements in the design of radionuclide treatment facilities.

In Chapter 7, the results of the previous chapters are discussed in a broader perspective. Besides the current role of tailored dosimetry in DTC also the potential benefits of this approach are discussed together with the technical challenges and novel developments on ${ }^{124}$ I PET-based lesion dosimetry. 




\section{Samenvatting}



Het doel van deze thesis is het verbeteren van stralingsdosisberekeningen van patiënten met gedifferentieerd schildklierkanker die behandeling met radioactief jodium ondergaan. Dit betreft zowel de toepassing van een gepersonaliseerde patiënt behandeling waarbij gebruik wordt gemaakt van kwantitatieve ${ }^{124}$ I PET imaging, als de bescherming tegen ioniserende straling van personeel en leden van de bevolking. Voor wat betreft patiënt management kan de toepassing van laesie dosimetrie, gebaseerd op pre-therapeutische ${ }^{124}$ I PET imaging, waardevolle prognostische informatie verschaffen en gepersonaliseerde therapie met radioactief jodium mogelijk maken. Een gepersonaliseerde therapie benadering faciliteert dosis escalatie en kan de kans op succesvolle therapie verbeteren, hetgeen in het bijzonder van belang is voor hoog-risico schildklierkanker patiënten. Bovendien zou gepersonaliseerde jodiumtherapie, voor patiënten met laesies die veel radioactief jodium opnemen, kunnen resulteren in het gebruik van lagere hoeveelheden radioactief jodium en een afname van de nadelige effecten ten gevolge van de therapie.

Vanuit het perspectief van stralingsbescherming kan nauwkeurige dosimetrie leiden tot verbeteringen van afschermingsmaatregelen in radionuclide therapiekamers welke veilig, kosteneffectief en in overeenstemming met de vigerende wet- en regelgeving zijn.

In Hoofdstuk 1 wordt een algemene introductie met betrekking tot de toepassing van radioactief jodiumtherapie in gedifferentieerd schildklierkanker gegeven. Daarnaast wordt het concept van gepersonaliseerde, pre-therapeutische stralingsdosisberekeningen aan laesies, gebaseerd op hybride PET/CT en PET/MRI beeldvorming, beschreven voor jodiumtherapie bij gedifferentieerd schildklierkanker. Tot slot wordt het gebruik van Monte Carlo gebaseerde dosimetrie bij jodiumtherapie, ten behoeve van stralingsbescherming van personeel en leden van de bevolking, beschreven.

Hoofdstuk 2 verschaft een uiteenzetting van de literatuur betreffende gepersonaliseerde dosimetrie methodieken en relevante ontwikkelingen in moleculaire nucleaire therapie. De mogelijkheden van het gebruik van geavanceerde, gepersonaliseerde dosimetrie in radionuclidentherapie zijn aangetoond en ontwikkelingen op het gebied van beeldvormende instrumentatie en dosimetrie software binnen de nucleaire geneeskunde vinden op hoog tempo plaats. De tot dusver ontwikkelde gepersonaliseerde procedures verschillen echter in benadering en complexiteit en standaard werkinstructies noodzakelijk voor een wijdverbreide implementatie zijn slechts in geringe mate beschikbaar.

In Hoofdstuk 3 is de dosis-response relatie van jodiumtherapie ten behoeve van schildklierkanker onderzocht in een retrospectieve studie middels berekening van de stralingsdosis welke door laesies is ontvangen tijdens therapie. De dosisberekening is hierbij uitgevoerd op basis van ${ }^{124}$ I PET/CT onderzoeken uitgevoerd voorafgaand aan de jodiumtherapie. Door gebruik te maken van een nieuwe segmentatiemethode, waarmee een nauwkeurige schatting van het volume verkregen kan worden voor laesies groter dan het ${ }^{124}$ I PET spatiële resolutievolume, hebben we gedemonstreerd dat laesies 
welke volledig respondeerden op de jodiumtherapie een statistisch significant hogere stralingsdosis hebben ontvangen dan laesies die niet of onvolledig respondeerden. Bovendien is met een 'receiver operating characteristic curve' analyse aangetoond dat pre-therapeutische ${ }^{124}$ I PET/CT laesie dosimetrie gebruikt kan worden als een prognostisch middel om de respons van laesies op therapie met radioactief jodium te voorspellen.

Nauwkeurige ${ }^{124}$ I kwantificatie, en dus de berekening van de stralingsdosis van laesies, wordt beïnvloed door de detectie van zogenaamde prompt gamma coïncidentie (PGC) events van ${ }^{124}$ I. Verschillende technieken om te corrigeren voor dit PGC effect zijn onderzocht en sinds kort commercieel beschikbaar. In Hoofdstuk 4 hebben we de impact van een PGC correctietechniek op de ${ }^{124}$ I PET/CT kwantificatie onderzocht voor zowel fantoom- als patiëntdata. Daarnaast is het effect van de PGC correctie op de berekende stralingsdosis ontvangen door laesies bepaald. Voor fantoom metingen leidde de PGC correctie tot een substantiële verbetering van de achtergrond uniformiteit. Bovendien resulteerde PGC correctie in significant hogere 'sphere recovery coefficient' waardes, ${ }^{124}$ I opname en berekende stralingsdosis van laesies en dient toegepast te worden indien dit beschikbaar is.

Vanwege het superieure weke-delen contrast van MRI ten opzichte van CT in hoofdhals imaging bestaat de mogelijkheid dat ${ }^{124}$ I PET/MRI in toenemende mate een belangrijke rol zal gaan spelen in gedifferentieerd schildklierkanker. Kwantitatieve PET/MRI is echter aanzienlijk complexer dan PET/CT, waarbij gebruik wordt gemaakt van een relatief eenvoudige CT-gebaseerde correctie voor PET verzwakking. In Hoofdstuk 5 is de kwantitatieve performance van ${ }^{124}$ I PET/MRI, met als doel het toepassen van laesie dosimetrie in gedifferentieerd schildklierkanker, onderzocht. Middels fantoom metingen is aangetoond dat de radioactiviteitsconcentratie van ${ }^{124}$ I werd onderschat met $12 \%$. De invloed van verzwakking van de MRI spoelen op de ${ }^{124}$ I kwantificatie bleek minder dan $5 \%$ te bedragen en werd als verwaarloosbaar beschouwd. De standaard MR-gebaseerde verzwakkingscorrectie waarin botweefsel wordt genegeerd, resulteerde in een verdere onderschatting in de gemeten ${ }^{124}$ I activiteitsconcentratie voor gesimuleerde laesies die de eigenschappen van bot hadden. Deze onderschatting nam toe met toenemende laesie dichtheid en diameter. Voor gedifferentieerd schildklierkankerpatiënten werd in een klinische setting een zeer goede overeenkomst gevonden met betrekking tot het gesegmenteerde laesievolume en de ${ }^{124}$ I radioactiviteitsconcentratie gemeten met PET/MRI en PET/CT. Daarom concludeerden wij dat een nauwkeurige schatting van de stralingsdosis ontvangen door laesies tijdens jodiumtherapie mogelijk is aan de hand van ${ }^{124}$ I PET/MR imaging.

Naast de bepaling van de stralingsdosis ontvangen door laesies, speelt dosimetrie ook een belangrijke rol in het afschermingsontwerp van radionuclidentherapieruimtes. In praktijk is de afscherming vaak aangebracht tot een hoogte lager dan de hoogte van het plafond. Hierdoor kan straling, welke over de afscherming gaat, verstrooid worden aan het plafond en een belangrijke bijdrage leveren aan de totale stralingsdosis buiten 
de radionuclidentherapieruimte. Op basis van Monte Carlo simulaties is in Hoofdstuk 6 de bijdrage van deze verstrooide straling ten opzichte van de totale stralingsdosis onderzocht. Zoals verwacht vonden we dat de dikte van de afscherming, nodig voor de afscherming van de primaire straling, uitgedrukt in het aantal halveringsdiktes, een belangrijke factor is voor de relatieve bijdrage van de straling verstrooid aan het plafond. Voor situaties waarin de dikte van de afscherming meer dan ongeveer vier halveringsdiktes bedraagt, kan straling verstrooid aan het plafond zelfs de dominante factor worden en dient deze dus meegenomen te worden in het ontwerp van de afscherming. De resultaten van deze studie maken de optimalisatie van het ontwerp van afscherming van radionuclidentherapieruimtes mogelijk.

In Hoofdstuk 7 worden de resultaten van de voorafgaande hoofdstukken bediscussieerd in een breder perspectief. Naast de huidige rol van gepersonaliseerde dosimetrie in gedifferentieerd schildklierkanker worden tevens de mogelijke voordelen van deze benadering besproken samen met de technische uitdagingen en nieuwe ontwikkelingen op het gebied van ${ }^{124}$ I PET-gebaseerde laesie dosimetrie. 